Vol. 74, No. 6, 2000]

分解酵素は，アルドキシム脱水酵素と密接にリンクし て存在していることが判明した (Fig. 2).

今後, $\beta$ メメルアスパルターゼのX-線結晶構造解析 を継続し高次構造を明らかにするとともに，その結果 をもとにして本醇素を改变したい，また，自然界にお けるアルドキシムの代謝経路および生合成経路を解明 し，さらに有機合成へと応用していきたい．

最後に，本研究をご援助いただきました財団法人農 芸化学研究将励会に深く感謝いたします。

(1) Y. Asano and Y. Kato: Biosci. Biotechnol. Biochem., 58, 223-224 (1994).

(2) Y. Asano and Y. Kato: FEMS Microbiol. Lett., 118, 255-258 (1994).

(3) Y. Kato and Y. Asano: Biosci. Biotechnol. Biochem., 59, 93-99 (1995).
第 26 回（1998 年度）研究奖励金受領者研究報告

687

(4) Y. Kato and Y. Asano: Appl. Microbiol. Biotech nol., 43, 901-907 (1995).

(5) Y. Kato and Y. Asano: Arch. Microbiol., 168, 457 -463 (1997).

(6) Y. Kato and Y. Asano: Appl. Microbiol. Biotechnol., 50, 468-474 (1998).

(7) Y. Asano and Y. Kato: FEMS Microbiol. Lett., 158, 185-190 (1998).

(8) Y. Kato, R. Ooi, and Y. Asano: Arch. Microbiol., 170, 85-90 (1998).

(9) Y. Kato, K. Nakamura, H. Sakiyama, S. G. Mayhew, and Y. Asano: Biochemistry, 39, 800809 (2000).

(10) Y. Kato, R. Ooi, and Y. Asano: J. Molec. Catal B: Enzymatic, 6, 249-256 (1999).

(11) Y. Kato, T. Tsuda, and Y. Asano: Eur. J. Biochem., 263, 662-670 (1999).
がんの転移，漫閏，および細胞骨格形成制御におけ る新規細胞膜亳打ちタンパク質ビネキシンの機能 解析

\section{京都大学農学研究科 木岡紀幸}

がん治療に扔ける最大の問題の一つにがんの転移, 浸潤がある，転移，浸潤を起こさせずにがんを原発巣 にだけ閉じ込めることができれば，外科的にがんを除 去することによってがんを治療することができる，が んの転移, 浸潤は細胞接着, 細胞移動, 細胞骨格の再 形成，細胞外マトリクスの分解，およびそれを制御す るシグナル伝達が密接に関連した多段階反応によりひ き起こされる．がんの克服のためにはこれらの各ステ ップのメカニズムを分子レベルで詳細に解明されるこ とが望まれている.

細胞外マトリクスと細胞の接着部位は接着斑と呼ば れ, 接着分子インテグリンとアクチン細胞骨格（スト レスファイバー) の末端, および, ビンキュリンや夕 リン, FAK (focal adhesion kinase) などの細胞膜裏 打タンパク質が集積している. 本研究では接着斑に局 在するビンキュリンに着目し，ビンキュリン結合タン パク質の解析から細胞接着とそれを制御するシグナル 伝達のメカニズムを解明しょうとした。.ビンキェリン はアクチンやタリンなど多くの細胞骨格関連タンパク 質と結合する重要なタンパク質である．特に注目すべ
きことはその結合活性がビンキュリンの構造変化によ り制御されていることである。そこでビンキュリンに 結合するタンパク質がビンキュリンの構造上機能の制 御を通じて細胞接着/細胞骨格の制御の力ギを握るの ではないかと考え，新規ビンキュリン結合タンパク質 ビネキシン (vinexin) を単離した(1).ビネキシンは C 末側にタンパク質相互作用ドメインである SH3 (Src homology 3) 領域を三つもつという非常に特徴的な 構造をしていた (図).

ビンキュリンとビネキシン間の結合に必要な領域を 明らかにするために，それぞれの欠失変異体を作成 $し$, two-hybrid 法と in vitro 結合アッセイ法を用い た解析を行った。をる結果，ビネキシンの1番目と2 番目の SH3 領域がビンキュリンのプロリン豊富領域 と結合することを明らかにした。興味深いことにっこ
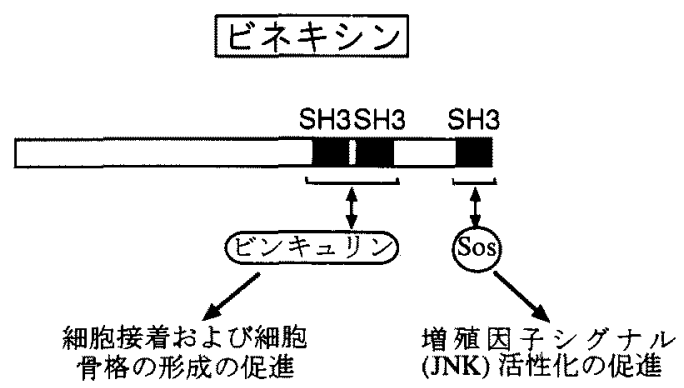

国 
の結合には二つの SH3 領域が必須であり，それぞれ 単独の SH3 領域では結合しなかった。

ビネキシンの機能を明らかにするために繊維芽細胞 NIH3T3 および上皮細胞 LLC-PK1 でビネキシンを強 制発現させた。 ビネキシンはビンキュリンと同じく細 胞接着斑と細胞間接着領域に局在した。 また，ビネキ シンの過剩発現は細胞外マトリクス(フィブロネクチ ン）への接着能を増強した。さらにアクチン細胞骨格 の形成にあ影響を与え，特に接着斑におけるアクチン ストレスファイバー末端の形成を強く促進することが わかった。これらの結果からビネキシンは細胞接着/ 細胞骨格の調節因子であることがわかった。

一方，ビンキュリンとの結合に関与しないビネキシ ンの 3 番目の SH3 領域は，増殖因子シグナル伝達分 子 Sos (Son of sevenless: 原かi九遗伝子 Ras O GDP/ GTP交換反応を促進L, Ras 活性化する)上invitro, in vivo で結合することを明らかにした(2). しかす，ビ ネキシンし Sos の結合は血清や上皮細胞増殖因子 (EGF) 刺激によって抑制されたことから，増殖因子シ グナルの制御に深くかかわっていると考えられる。奏 際，EGFで細胞を刺激した場合，Sos の下流に位置す ると考えられているMAPキ+ーゼの一種 JNK (c-Jun $N$ terminal kinase) の活性化がビネキシンの発 現によって増強されることがわかった．しかも，Sos との結合部位である 3 番目のSH3 領域に変異を導入 したビネキシンはEGFによるJNKの活性化をドミ
ナントネガティブに抑制した。これらの事実からビネ キシンは細胞接着/細胞骨格と増殖因子シグナルの鬲 万の制御に関与する分子であることが示唆された。

最近ビネキシンと良く似た構造をもつ分子，つまり $\mathrm{C}$ 末端側に三つの SH3 領域をむつタンパク質が相次 いで報告され(3 5)，新しい遗伝子ファミミリ一を形成 していることが明らかとなってきた。 これらの分子は いずれも細胞接着/細胞骨格とシグナル伝達の両者の 制御にかかわることから，この遗伝子ファミリーは細 胞の増殖や接着, 移動に重要な役割を果たしていると 考えられる.今後ビネキシンの機能解析を細胞のがん 化，転移のメカニズムの解明へ上発展させていきたい と考えている.

最後に，本研究に対してご援助いただきました財団 法人農芸化学研究将励会に深く感謝いたします。

(1) N. Kioka, S. Sakata, T. Kawauchi, T. Amachi, S. K. Akiyama, K. Okazaki, C. Yaen, K. M. Yamada, and S. Aota: J. Cell. Biol, 144, 59 (1999).

(2) M. Akamatsu, S. Aota, A. Suwa, K. Ueda, T. Amachi, K. M. Yamada, S. K. Akiyama, and N. Kioka: J. Biol. Chem. 274, 35933 (1999).

( 3 ) K. Mandai, H. Nakanishi, A. Satoh, K. Takahashi, K. Satoh, H. Nishioka, A. Mizoguchi, and Y. Takai: J. Cell. Biol., 144, 1001 (1999).

(4) V. Ribon, R. Herrera, B. K. Kay, and A. R. Saltiel: J. Biol. Chem., 273, 4073 (1998).

(5) B. Wang, E. A. Golemis, and G. D. Kruh: J. Biol. Chem., 272, 17542 (1997).

\section{ヒト型ミルクオリゴ糖鎖の大量合成とその応用に 関する研究}

\section{静岡大学農学部 村田健臣}

ヒトミルク中にはラクトースを骨格にもつ 3 糖以 上のミルクオリゴ糖と総称される遊離オリゴ糖が存在 し, 腸内有用菌の增殖 ${ }^{(1)}$, 病原性細菌の接着阻止 ${ }^{(2)}$, 大 腸菌毒素中和 ${ }^{(3)}$ などの機能が認められている。これら のオリゴ糖のほとんどは, ラクト-N-テトラオース $(\mathrm{Gal} \beta 1 \rightarrow 3 \mathrm{GlcNAc} \beta 1 \rightarrow 3 \mathrm{Gal} \beta 1 \rightarrow 4 \mathrm{Glc})$ あるいはラク トーN-ネオテトラオース $(\mathrm{Gal} \beta 1 \rightarrow 4 \mathrm{GICNAc} \beta 1 \rightarrow 3 \mathrm{Gal} \beta$ $1 \rightarrow 4 \mathrm{Glc}$ ) 基本骨格としている(4).このようなミルク オリゴ糖は，これまで主にミルクからの調製により供
給されてきたため大量入手が困離で，生理機能の解明 や工学的な展開が大きく立ち後れていた。

そこでわれわれは，これまでに開発してきた醇素変 換技術 ${ }^{(5)}$ 基盤とし，さらに新戦略，新手法としてエ ンド型㧍よびエキン型糖質加水分解醉素の高位置選択 的な糖転移反応，糖ヌクレオチドを利用した糖転移醉 素による特異的糖転移反応を導入し, 従来では達成し えない効率的なヒト型ミルクオリゴ糖鎖基本 4 糖骨 格の大量合成法の開発を行った。すなわち，図に示す ように安価で大量に入手可能なうクトースを出発原料 とし, 順次 $N$-アセチルグルコサミニル化, ガラクトシ ル化を行うステップ合成法と，ラクトースにラクト。 $N$-ビオース I $(\mathrm{Gal} \beta 1 \rightarrow 3 \mathrm{Gl} \mathrm{cNAC})$ を 1 段階の反応で結 